\title{
Introduction to Part 3
}

Part 3 of the present book focuses on how the notion of independence interacts with the attempts by the EU Commission to control corporate bigness.

The topic of judicial independence - the classical locus of this notion - is fraught with the natural difficulty that accompanies all attempts to translate a moral value into a widely-applicable legal concept. Extracting independence from its natural location in order to apply it to administrative procedure adds another layer of difficulty. Finally, when these concepts are applied to a supranational bureaucracy like the European Commission, the task may appear insurmountable. However, it is often that which is the unbearable which requires urgent thought and action.

In the following chapters, I will attempt to answer the following questions:

- What is judicial independence and why is it important for a democracy?

- Who defines what judicial independence is?

- What is the role played by the case-law of the ECtHR in shaping the notion of judicial independence?

- What are the consequences of applying the notion of judicial independence to the procedures characterizing the administrative state?

- How is the EU Commission engaging with the concept of independence as an institution, as enforcer of competition law and as bureaucracy?

In Figure 8 below I offer a visual description of the proposed work.

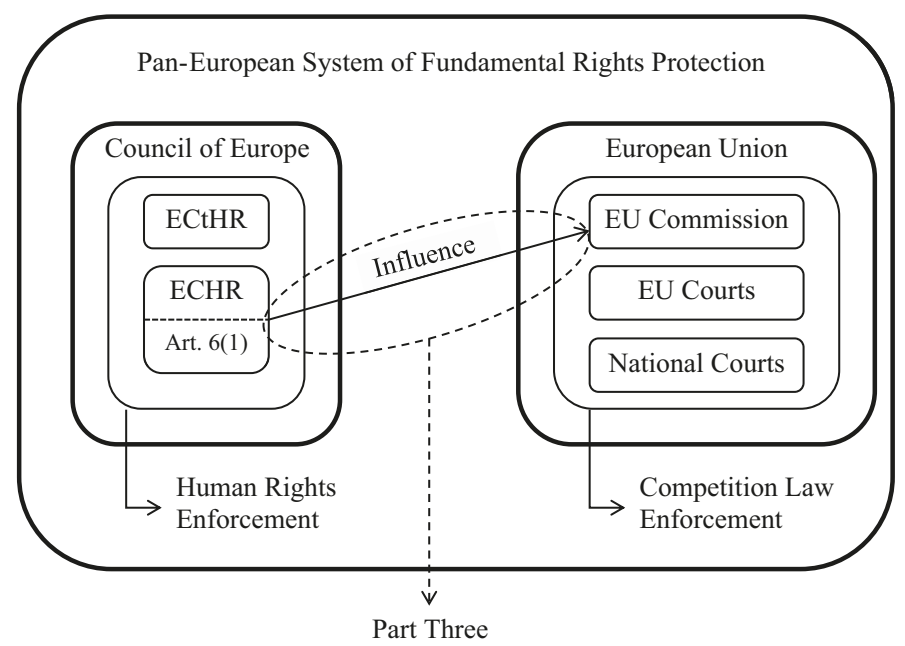

FIGURE 8 The influence of the case-law of the ECtHR on the independence of EU Commission 
The right to a fair trial enshrined in Article 6(1) ECHR provides that "in the determination of his civil rights and obligations or of any criminal charge against him, everyone is entitled to a fair and public hearing within a reasonable time by an independent and impartial tribunal established by law". As I have highlighted in the previous two chapters, this provision applies to disputes concerning economic law, including competition law. Also, the ECtHR developed a functional and teleological interpretation of the notion "independent and impartial tribunal established by law", equating the administrative agencies performing adjudicatory powers with the "tribunal established by law" required by Article 6(1) ECHR.

There are two immediately visible threats to the independence of the EU Commission as adjudicator in EU competition law disputes. The first is that the EU Commission cumulates investigative, prosecutorial and adjudicative functions when enforcing competition law. The second, as shown in Figure 5 above, the decisions adopted by the EU Commission in competition law cases are prepared by the bureaucratic branch of the Commission - DG COMP, assisted by other DG s - and are adopted by its political branch - the College of Commissioners. An argument regarding the Commission's independence in this area requires an analysis of both branches of the Commission.

To achieve this, I provide in Chapter 7 an in-depth analysis of the notion of judicial independence in the context of the administrative state. In Chapter 8 I review the case-law of the ECtHR on this subject. In Chapter 9 I describe the three constitutional functions that the EU Commission cumulates in the field of competition law - political, bureaucratic and enforcement. What is more, when the EU Commission acts as the enforcer of EU competition law, it cumulates the investigative, prosecutorial and adjudicative functions. For each of these functions, I identify the risks to independence and offer a description of the legal provisions to safeguard independence.

In Chapters 10, 11 and 12 I provide a description of the EU Commission's powers of investigation and the existing limits on its powers.

Finally, in Chapter 13 I describe the risks to independent adjudication identified in the enforcement procedure for Articles 101 and 102 TFEU and compare them to the existing safeguards provided in EU law. I conclude Chapter 13 with a risk-based framework for safeguarding the independence of the EU Commission as competition enforcement agency. 